\title{
PENGEMBANGAN MODUL PRAKTIKUM KIMIA BAHAN ALAM BERBASIS GENERIK SAINS: ISOLASI KAFEIN DARI BUBUK KOPI
}

\author{
Aenun Safitri", Aliefman Hakim, Baiq Fara Dwirani Sofia \\ Program Studi Pendidikan Kimia, Universitas Mataram. Jalan Majapahit No. 62 \\ Mataram, NTB 83112, Indonesia. \\ *Coressponding Author. E-mail: aenunsafitri10@gmail.com
}

Received: 29 Maret 2020

\author{
Accepted: 15 Mei 2020 \\ doi: 10.29303/cep.v3i1.1770
}

Publish: 29 Mei 2020

\begin{abstract}
Abstrak
Penelitian ini merupakan penelitian $R \& D$ (Research and Development) yang bertujuan untuk mengetahui: (1) langkah-langkah proses pengembangan modul praktikum kimia bahan alam berbasis generik sains tentang isolasi kafein dari bubuk kopi., (2) Tingkat kelayakan serta kepraktisan modul praktikum kimia bahan alam berbasis generik sains tentang isolasi kafein dari bubuk kopi yang sudah dikembangkan. Desain penelitian yang digunakan adalah model 4D (define, design, develop, and dissemination). Populasi dalam penelitian ini meliputi mahasiswa program studi pendidikan kimia angkatan 2016/2017 yang berjumlah 67 mahasiswa dan sudah memprogramkan mata kuliah kimia bahan alam. Sampel penelitian yaitu 15 mahasiswa yang diambil secara acak. Hasil penelitian menunjukkan nilai validitas dari tiga orang validator yang diperoleh menggunakan indeks Aiken's adalah $\mathrm{V}=0,7$ yang menunjukkan bahwa modul praktikum praktikum kimia bahan alam berbasis generik sains tentang isolasi kafein dari bubuk kopi telah valid dan layak digunakan. Sementara itu, praktikalitas dapat dilihat dari respon mahasiswa dan dosen yang menunjukkan respon positif dengan rata-rata praktikalitas semua komponen sebesar 85\% respon mahasiswa dan 94\% respon dosen. Berdasarkan data tersebut dapat disimpulkan bahwa modul praktikum kimia bahan alam berbasis generik sains tentang isolasi kafein dari bubuk kopi yang dikembangkan bersifat layak dan sangat praktis digunakan dalam proses pembelajaran.
\end{abstract}

Kata kunci: Pengembangan, Modul, Kimia Bahan Alam, Kopi, Kafein

\section{The Development of Natural Chemistry Laboratory Work Module Based on Generic Science: Caffein Isolation from Coffee Powder}

\begin{abstract}
This research is a Research and Development which focused on discovering: (1) Steps in the process of developing a natural material chemistry lab module about the isolation of caffein from coffee powder. (2) The level of feasibility and practicality of the natural material chemistry lab module about the isolation of caffein from coffee powder that have been developed. The research design used was the 4D model (Define, Design, Develop, and Disseminate). The population in this study included all students of the 2016/2017 academic chemistry study program who programed natural material chemistry courses. While the sample in this study was fifteen students were taken randomly. The results showed that the validity of the two validators obtained using the Aiken's index was $V=0.7$ indicating that the natural material chemistry practicum module was about isolation of caffein from coffee powder is valid and suitable for use. Meanwhile, practicality can be seen from the responses of students and lecturers who showed a positive response with the practicality of all module components amounting to $85 \%$ of student responses and $94 \%$ of lecturers' responses. Based on these data, it can be concluded that the module on the chemistry of natural materials about the isolation of caffein from coffee powder developed is feasible and practical so that it can be used in the learning process.
\end{abstract}

Keywords: Development, Practicum module, Natural Product Chemistry, Coffee, Caffein 


\section{Chemistry Education Practice,3 (1), 2020 - 48}

Safitri, Hakim, Sofia

\section{PENDAHULUAN}

Erwanto \& Santoso (2016: 428) menjelaskan bahwa Tujuan dari pendidikan adalah menghasilkan sumber daya manusia yang berkualitas, sehingga mampu bersaing dengan tenaga kerja lain sesuai kompetensi yang dimilikinya dalam menghadapi persaingan global $^{[1]}$. Pendidikan sendiri adalah proses pembelajaran yang dapat membantu seseorang dalam mengembangkan potensinya (Gustinasari, Lufri \& Ardi, 2017: 60). Salah satu lembaga pendidikan yang memiliki peranan sangat besar dalam meningkatkan kualitas sumber daya manusia adalah perguruan tinggi (Nulhaqim, Heryadi, Pancasilawan \& Fedriyansyah, 2015: 197). Program studi pendidikan kimia merupakan salah satu lembaga pendidikan di perguruan tinggi yang memiliki peranan dalam meningkatkan kualitas sumber daya manusia melalui kegiatan pembelajaran akademik dan keterampilan. Keterampilan mahasiswa dapat ditingkatkan melalui kegiatan praktikum pada pembelajaran kimia.

Salah satu mata kuliah yang wajib bagi mahasiswa program studi pendidikan kimia adalah kimia bahan alam. Mata kuliah ini diberikan di semester 6. Kimia Bahan Alam mempelajari tentang senyawa metabolit sekunder yang terdiri atas struktur, sifat dan asal usul biosintesis senyawa polifenol, terpenoid, steroid, flavonoid, alkaloid dan beberapa senyawa alam yang berguna serta melakukan isolasi metabolit sekunder dan mengkomunikasikannya (Hakim et al., 2019). Kegiatan pembelajaran Kimia Bahan Alam tidak dapat lepas dari kegiatan praktikum. Praktikum sendiri merupakan bentuk pembelajaran yang dilakukan pada suatu tempat tertentu, dimana mahasiswa berperan aktif dalam menyelesaikan problem yang diberikan melalui penggunaan alat, bahan dan metode tertentu (Mahmudah, Sukib \& Hakim, 2018: 20). Melalui kegiatan praktikum tentunya diharapkan mahasiswa akan memperoleh pengalaman secara langsung, sehingga dapat meningkatkan penguasaan konsep, kemampuan memecahkan masalah dan keterampilan ilmiah, memahami bagaimana sains dan ilmuwan bekerja, menumbuhkan minat dan motivasi serta melatih keterampilan berpikir. Salah satu keterampilan berpikir yang dapat dikembangkan adalah keterampilan generik sains. Modul praktikum yang digunakan harusnya dapat mengarahkan mahasiswa sehingga dapat meningkatkan keterampilan generik sains (Pujiani, 2014: 472-473).

Keterampilan generik sains adalah keterampilan berpikir dan bertindak berdasarkan pengetahuan sains yang dimilikinya. Keterampilan generik sains merupakan kemampuan yang digunakan secara umum dalam berbagai kerja ilmiah dan dapat digunakan sebagai landasan dalam melakukan kegiatan praktikum (Pujiani, 2014: 473). Keterampilan generik yang dapat dikembangkan melalui pembelajaran sains adalah pengamatan langsung, pengamatan tak langsung, pemahaman tentang skala, bahasa simbolik, logical frame, kosistensi logik, hukum sebab akibat, pemodelan, logical inference, dan membangun konsep (Agustin, 2013: 254).

Kegiatan praktikum Kimia Bahan Alam yang biasa dilakukan yaitu memisahkan senyawa metabolit sekunder dari bahan-bahan alam. Atun (2014: 54) menjelaskan bahwa senyawa metabolit sekunder berupa molekulmolekul kecil, bersifat spesifik artinya tidak semua organisme mengandung senyawa sejenis, mempunyai struktur yang bervariasi dan setiap senyawa memiliki fungsi/peran yang berbedabeda. Senyawa metabolit sekunder dapat dipisahkan dari bahan-bahan alam melalui proses isolasi yang terdiri atas ekstraksi, fraksinasi, pemurnian dan identifikasi (Mahmudah dkk., 2018: 21). Isolasi adalah proses pemisahan suatu komponen kimia yang diinginkan dari komponen-komponen lainnya yang bersifat sebagai kontaminan dalam suatu bahan (Wasia, Sudarma, Savalas \& Hakim, 2017: 91).

Praktikum akan berjalan baik jika disertai dengan sebuah modul yang dijadikan sebagai pedoman praktikum. Modul secara umum dapat diartikan sebagai satuan program pembelajaran terkecil yang dapat dipelajari mahasiswa secara perseorangan (self instructional), setelah menyelesaikan satu satuan dalam modul, selanjutnya mahasiswa dapat melangkah maju dan mempelajari satuan modul berikutnya (Mahmudah dkk., 2018: 21).

Berdasarkan hasil observasi, praktikum kimia bahan alam diterapkan dengan kegiatan berbasis proyek. Kegiatan praktikum berbasis proyek dilakukan dengan memberikan kesempatan bagi mahasiswa untuk menyelesaikan kegiatan praktikum secara sendiri, namun tetap dalam bimbingan dosen pengampu. Dengan kegiatan praktikum berbasis 


\section{Chemistry Education Practice,3 (1), 2020 - 49}

Safitri, Hakim, Sofia

proyek, mahasiswa tentunya akan menjadi lebih aktif bahkan kreatif.

Untuk menghindari hal-hal yang tidak diinginkan yang dapat menghambat atau membuat praktikum gagal, diperlukan suatu modul yang dapat digunakan oleh mahasiswa sebagai pedoman dalam melaksanakan praktikum. Selama ini hanya ada satu modul kimia bahan alam yang digunakan yaitu modul praktikum isolasi curcumin dari kunyit. Agar ada lebih banyak sumber belajar berupa modul praktikum dan tumbuhan yang dimanfaatkan lebih bervariasi, maka perlu dilakukan pengembangan modul praktikum isolasi senyawa dari tumbuhan yang berbeda.

Salah satu jenis tumbuhan yang dapat dimanfaatkan adalah kopi. Kopi adalah bijibijian dari jenis coffea dengan kandungan alamiah berupa kafein, sitosterin, kolin dan terpenoid. Senyawa yang banyak dikenal masyarakat dalam kopi adalah kafein dan kandungan kafein yang paling banyak terdapat pada bagian biji kopi (Misfadhila, Zulharmita \& Siska, 2016: 175). Kafein termasuk kelompok metilxantin merupakan senyawa yang terbentuk secara alami dan termasuk dalam derivat xantin yang termasuk golongan alkaloid (Fajriana \& Fajriati, 2018: 149).

Kafein merupakan salah satu jenis alkaloid yang tidak hanya terdapat pada biji kopi, namun terdapat juga pada daun teh dan biji coklat. Berdasarkan uji pendahuluan yang telah dilakukan, kristal kafein yang dihasilkan pada isolasi dari bubuk kopi lebih banyak dan lebih murni dibanding kristal kafein yang diisolasi dari daun teh. Berdasarkan penelitian yang dilakukan oleh Nugraheni, Dewi \& Septiyana (2017: 47), nilai rendemen kristal kafein pada biji kopi lebih tinggi daripada coklat dengan nilai perbandingan $1: 2,79$. Sehingga kandungan kafein pada biji kopi lebih banyak daripada daun teh dan biji coklat.

Berdasarkan penelitian yang dilakukan oleh Misfadhila dkk. (2016), kafein berhasil diisolasi dari bubuk kopi dengan metode kristalisasi yang menghasilkan kafein dengan berat $128 \mathrm{mg}$. Pada penelitian ini, metode isolasi dari Misfadhila dkk. (2016) dimodifikasi dengan mengganti pelarut dari diklorometana menjadi kloroform yang lebih murah, tidak menggunakan bahan $\mathrm{MgSO}_{4}$ serta tidak dilakukannya tahap evaporasi. Dengan metode modifikasi ini diharapkan tetap dapat menghasilkan kristal kafein yang murni dengan rendemen yang tinggi. Sehingga dihasilkan modul praktikum dengan langkah yang lebih singkat dan penggunaan bahan menjadi lebih sedikit (lebih ekonomis).

Berdasarkan latar belakang di atas, penulis akan melakukan penelitian yang berjudul "Pengembangan Modul Praktikum Kimia Bahan Alam Berbasis Generik Sains: Isolasi Kafein darik Bubuk Kopi”.

\section{METODE}

Sebelum melaksanakan penelitian, terlebih dahulu dibuat proposal penelitian. Waktu yang diperlukan dalam pembuatan proposal yakni bulan Agustus-Oktober 2019. Pelaksanaan penelitian dilakukan pada bulan Oktober 2019-Januari 2020. Tempat pelaksanaan penelitian di Fakultas Keguruan dan Ilmu Pendidikan, Universitas Mataram.Penelitian ini menggunakan model 4D (define, design, develop, and dissemination) yang dikemukakan oleh Thiagarajan dkk. (1974: 5). Model 4D terdiri dari pendefinisian (define), perancangan (design), pengembangan (develop), dan penyebaran (disseminate). Namun, pengembangan yang dilaksanakan pada penelitian ini hanya dibatasi sampai pada tahap ketiga yaitu pengembangan (develop). Adapun yang dikembangkan dalam penelitian ini yaitu modul praktikum kimia bahan alam berbasis generik sains tentang isolasi kafein dari bubuk kopi.

Populasi dalam penelitian ini adalah Mahasiswa Program Studi Pendidikan Kimia, Fakultas Keguruan dan Ilmu Pendidikan, Universitas Mataram angkatan 2016 yang terdiri dari tiga kelas dengan jumlah mahasiswa secara keseluruhan adalah 67 orang. Pada saat penelitian ini berlangsung sedang menempuh semester VII atau sudah mengambil mata kuliah kimia bahan alam. Sebagai sampel, dipilih secara acak sebanyak 15 orang dari populasi.

Penelitian ini menggunakan dua jenis instrumen. Dalam pengambilan data untuk menguji kelayakan modul, menggunakan instrumen berupa validitas ahli. Sedangkan, pengambilan data untuk menguji kepraktisan modul menggunakan instrumen berupa angket yang kemudian diserahkan kepada mahasiswa (sampel) dan dosen mata kuliah Kimia Bahan Alam. Lembar validasi modul dianalisis dengan statistik Aiken's V dan angket respon mahasiswa dan dosen dianalisis menggunakan skala praktikalitas. 


\section{HASIL DAN PEMBAHASAN}

Masing-masing tahapan kegiatan pengembangan modul praktikum yang dilakukan beserta analisis data yang diperoleh, dapat dideskripsikan sebagai berikut:

\section{Tahap Pendefinisian (Define)}

Pendefinisian (Define) merupakan tahap paling awal dalam penelitian. Pada tahap ini dilakukan analisis awal akhir dan analisis materi. Hasil analisis diperoleh dari studi literatur pada beberapa jurnal serta Rancangan Pembelajaran Semester (RPS) dan Rancangan Tugas Mahasiswa (RTM).

Berdasarkan hasil analisis terhadap Rancangan Pembelajaran Semester (RPS) yang terdiri dari kemampuan akhir yang diharapkan, bahan kajian serta indikator capaian, maka modul praktikum yang dikembangkan dapat digunakan dalam satu semester yaitu terdiri dari 3 (1) sks berisi 16 pertemuan dengan rincian 8 pertemuan materi teoritis (termasuk UTS dan UAS) yang dilakukan dengan pembelajaran tatap muka di kelas dan 8 pertemuan digunakan untuk praktikum isolasi senyawa metabolit sekunder yaitu isolasi kafein dari bubuk kopi.

Hal ini juga diperkuat dengan hasil analisis terhadap Rancangan Tugas Mahasiswa (RTM) yang terdapat pada uraian tugas berupa kegiatan mengisolasi senyawa metabolit sekunder yang dikerjakan mahasiswa secara berkelompok berbasis proyek yang terdiri dari membuat proposal sederhana tentang isolasi kafein dari bubuk kopi dengan mengacu pada modul praktikum, mempresentasikan proposal yang telah dibuat, mengimplementasikan proposal isolasi kafein dari bubuk kopi yang telah disetujui dosen dan menyusun laporan serta mempresentasikan hasil implementasi praktikum. Sehingga luaran tugas yang dihasilkan berupa tugas kelompok yang dibuat dalam bentuk proposal sederhana mengenai isolasi kafein dari bubuk kopi yang diimplementasikan di laboratorium serta membuat laporan praktikum tentang isolasi kafein dari bubuk kopi.

Analisis jurnal mengenai isolasi kafein dari bubuk kopi bertujuan untuk mengetahui proses isolasi kafein dari bubuk kopi, karakteristik senyawa dan pelarut yang digunakan serta tujuan praktikum yang akan dicapai. Berdasarkan analisis jurnal tersebut peneliti membuat rangkaian skema kerja isolasi kafein dari bubuk kopi yang terdiri dari skema kerja utama dan skema kerja modifikasi. Skema kerja modifikasi tersebut dijadikan sebagai acuan untuk melakasanakan praktikum isolasi kafein dari bubuk kopi dengan metode ekstraksi caircair yang kemudian dikristalisasi dan direkristalisasi.

Berdasarkan praktikum tentang isolasi kafein dari bubuk kopi yang telah dilakukan didapatkan kristal kafein berwarna putih berbentuk jarum dengan berat kristal sebesar 0,1754 gram dengan rendemen sebesar $0,50 \%$. Kristal kafein yang didapatkan kemudian dimurnikan menggunakan Kromatografi Lapis Tipis (KLT) yang dilihat menggunakan $U V$ lamp sehingga terlihat spot berwarna biru berjumlah satu spot. Kristal kafein kemudian dianalisis dengan spektroskopi IR dan spektroskopi UV-Vis. Berdasarkan hasil analisis spektroskopi IR didapatkan spektrum kafein dengan kemiripan $\pm 95 \%$ dengan spektrum yang ada pada literatur. Gugus-gugus fungsi yang teridentifikasi pada spektrum IR hasil isolasi sesuai dengan gugus fungsi yang ada pada struktur kafein. Gugus fungsi N-H ditunjukkan pada kisaran 3310-3500 $\mathrm{cm}^{-1}$, gugus $\mathrm{C}-\mathrm{H}$ ditunjukkan pada kisaran $3000-3100 \mathrm{~cm}^{-1}$, gugus $\mathrm{C}=\mathrm{C}$ aromatik ditunjukkan pada kisaran 1500$1600 \mathrm{~cm}^{-1}$ dan gugus $\mathrm{C}-\mathrm{N}$ ditunjukan pada kisaran 1180-1360 $\mathrm{cm}^{-1}$. Berikut gambar spektrum IR kafein Hasil isolasi:

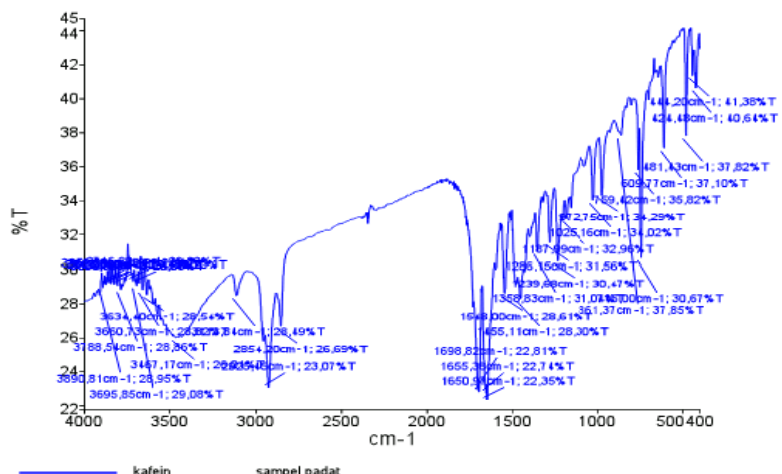

Gambar 1. Spektrum IR kafein Hasil isolasi

Pada analisis spektroskopi UV-Vis didapatkan puncak (peak) tertinggi pada panjang gelombang 273,20 nm. Hal ini menunjukkan bahwa struktur senyawa kafein memiliki ikatan rangkap terkonjugasi, dimana puncak (peak) ikatan rangkap terkonjugasi berada pada panjang gelombang diatas $250 \mathrm{~nm}$. Berikut gambar spektrum UV-Vis kafein hasil isolasi: 


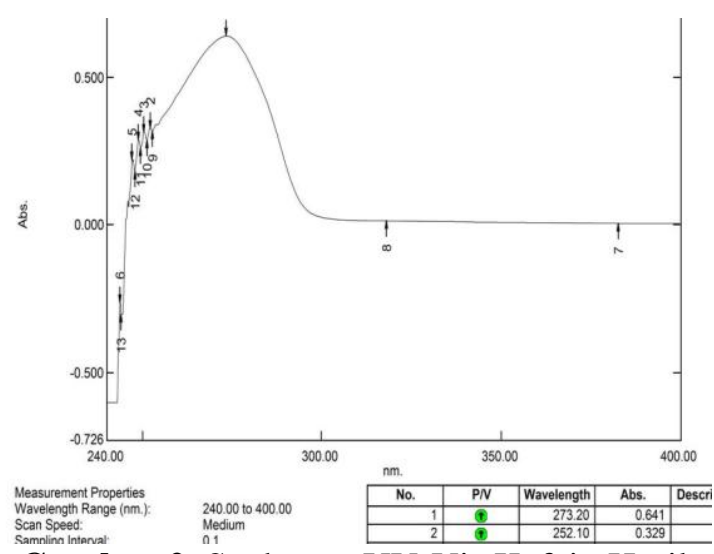

Gambar 2. Spektrum UV-Vis Kafein Hasil Isolasi

Berdasarkan hasil praktikum tersebut, dapat disimpulkan bahwa serbuk yang didapatkan oleh peneliti pada praktikum adalah senyawa kafein, sehingga metode praktikum yang digunakan dapat dijadikan sebagai acuan untuk proses pembuatan modul praktikum kimia bahan alam berbasis generik sains tentang isolasi kafein yang dikembangkan.

Berdasarkan hasil analisis diatas, modul praktikum yang dirancang bertujuan untuk dapat mengisolasi senyawa kafein dari bubuk kopi dengan metode ekstraksi cair-cair, kristalisasi dan rekristalisasi. Sehingga materi yang dipaparkan pada modul praktikum terdiri dari materi teoritis dan prosedural yang disusun untuk meningkatkan keterampilan generik sains mahasiswa. Materi-materi ini dipaparkan dari beberapa buku kimia bahan alam dan jurnal mengenai isolasi senyawa metabolit sekunder. Adapun materi teoritis terdiri dari pengertian dan tujuan isolasi, peralatan dan bahan-bahan isolasi senyawa metabolit sekunder, ekstraksi senyawa metabolit sekunder yang terdiri dari pengertian ekstraksi, polaritas pelarut dan pemilihan pelarut, faktor-faktor yang mempengaruhi ekstraksi serta penentuan struktur senyawa metabolit sekunder. Selain itu, diberikan pemaparan mengenai karakteristik buah kopi serta senyawa kafein yang akan diisolasi dari kopi tersebut. Adapun materi prosedural, diberikan pemaparan mengenai proses ekstraksi cair-cair, kristalisasi dan rekristalisasi, pemurnian senyawa hasil rekristalisasi menggunakan Kromatografi Lapis Tipis dan analisis spektroskopi IR dan UV-Vis.

\section{Tahap Perancangan (Design)}

Tahap perancangan merupakan langkah selanjutnya yang dilakukan berdasarkan beberapa hasil identifikasi pada tahap pendefinisian atau analisis. Pada tahap ini dilakukan penyusunan modul yang diawali dengan perancangan cover, penyusunan komponen modul (1) yaitu kata pengantar, daftar isi, tata tertib praktikum dan pengenalan laboratorium kimia, (2) proses praktikum, berisi tentang judul praktikum, tujuan praktikum, materi terkait dengan praktikum, prosedur kerja, hasil pengamatan, pengolahan data, pertanyaan dan pembahasan praktikum. Setelah melakukan perancangan terhadap modul praktikum, didapatkan hasil dari tahap perancangan atau design yaitu berupa prototype 1 .

\section{Tahap Pengembangan (Development)}

Perangkat pembelajaran yang

dikembangkan dapat dikatakan berkualitas apabila memenuhi kriteria sebagai berikut yaitu (1) validitas (validity) dan kepraktisan (praticality). Penelitian ini bertujuan untuk menghasilkan produk berupa modul praktikum yang layak dan praktis untuk digunakan dalam proses pembelajaran. Pada tahap ini produk awal (prototype 1) yang dihasilkan diuji kevalidannya dengan uji validitas untuk mendapatkan masukan serta saran yang membangun agar modul praktikum yang dikembangkan lebih baik dan layak digunakan sebagai media praktikum. Uji validitas tersebut menggunakan instrumen berupa lembar validasi ahli yang berisi komponen kegrafikan, komponen penyajian, komponen kelayakan isi dan komponen kebahasaan. Instrumen penelitian tentunya berkenaan dengan validitas dan reliabilitas (Sugiyono, 2015: 409).

Analisis yang digunakan dalam menentukan tingkat kevalidan modul yaitu indeks Aiken dimana validitas di lakukan pada tiga orang validator. Berikut grafik kelayakan (validitas) modul yang dikembangkan:

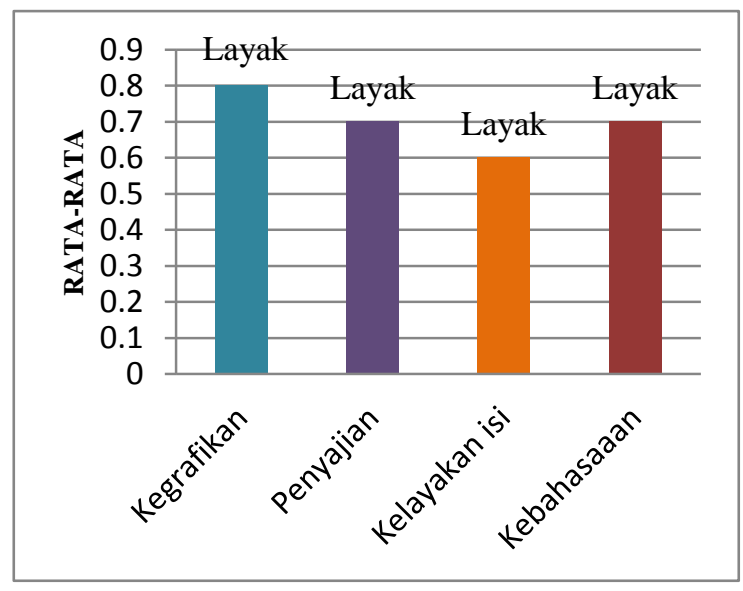

Gambar 3. Kelayakan Modul 


\section{Chemistry Education Practice,3 (1), 2020 - 52}

Safitri, Hakim, Sofia

Dari ketiga validator memberikan nilai valid terhadap modul praktikum dan dapat digunakan setelah melakukan revisi sesuai dengan saran-saran yang sudah diberikan. Setelah melakukan validasi terhadap modul praktikum maka didapatkan hasil dari tahap pengembangan yaitu prototype 2. Selanjutnya prototype 2 diuji cobakan kepada mahasiswa dan dosen pendidikan program studi Pendidikan Kimia tahun akademik 2019/2020, Fakultas Keguruan dan Ilmu Pendidikan, Universitas Mataram.

Uji coba yang dilakukan adalah uji coba skala terbatas yaitu pada 15 orang mahasiswa program studi pendidikan kimia dan dua orang dosen pendidikan kimia, Universitas Mataram. Pada tahap ini, uji coba dilaksanakan untuk memperoleh respon mahasiswa dan dosen terhadap modul praktikum yang dikembangkan. Angket respon mahasiswa dan dosen yang digunakan terdiri dari 21 butir pernyataan dimana sepuluh pernyataan untuk komponen kemenarikan modul, tujuh pernyataan untuk komponen kemudahan penggunaan modul, dua pernyataan untuk komponen waktu pelaksanaan modul dan dua pernyataan untuk komponen manfaat modul. Setelah menganalisis angket respon mahasiswa dan dosen diperoleh rata-rata mahasiswa dan dosen menunjukkan respon baik terhadap modul praktikum yang telah dikembangkan. Praktikalitas semua komponen modul diperoleh nilai rata-rata respon mahasiswa sebesar $85 \%$ dan nilai rata-rata respon dosen sebesar $94 \%$ yang menunjukkan modul praktikum yang dikembangkan berada pada kategori sangat praktis. Berikut grafik hasil respon mahasiswa dan dosen terhadap modul yang dikembangkan:

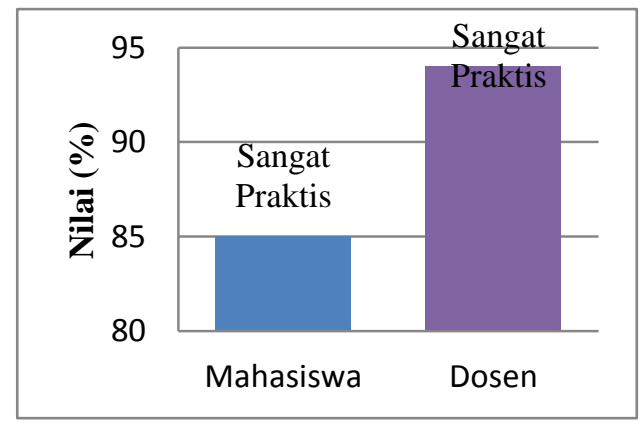

Gambar 4. Kepraktisan Modul

Setelah dilakukan validasi dan uji coba terhadap modul praktikum, maka didapatkan hasil dari tahap pengembangan yang disebut dengan prototype 3 . Berdasarkan hasil validasi serta angket respon mahasiswa dan dosen, maka diperoleh kesimpulan bahwa modul praktikum kimia bahan alam berbasis generik sains tentang isolasi kafein dari bubuk kopi telah valid (layak) dan praktis digunakan dalam proses pembelajaran.

Dimana Indikator keterampilan generik sains yang dikembangkan pada modul ini terangkum dalam Tabel 1 berikut ini.

Tabel 1. Indikator Keterampilan Generik Sains dan Aktivitas Mahasiswa

\begin{tabular}{lll}
\hline No & \multicolumn{1}{c}{$\begin{array}{c}\text { Indikator } \\
\text { Keterampilan } \\
\text { Generik Sains }\end{array}$} & Aktivitas Mahasiswa \\
\hline 1. & $\begin{array}{l}\text { Pengamatan tak } \\
\text { langsung }\end{array}$ & $\begin{array}{l}\text { Menggunakan alat ukur } \\
\text { sebagai alat bantu } \\
\text { indera dalam } \\
\text { mengamati percoban. }\end{array}$ \\
2. & $\begin{array}{l}\text { Kesadaran } \\
\text { tentang skala }\end{array}$ & $\begin{array}{l}\text { Menyadari objek-objek } \\
\text { alam dan kepekaan } \\
\text { yang tinggi terhadap } \\
\text { skala numerik sebagai } \\
\text { besaran atau ukuran } \\
\text { skala mikroskopis } \\
\text { ataupun makroskopis. } \\
\text { Menggunakan simbol, } \\
\text { lambang dan istilah } \\
\text { kimia. } \\
\text { Dapat digunakan untuk } \\
\text { menarik kesimpulan } \\
\text { secara induktif setelah } \\
\text { melakukan pecobaan. }\end{array}$ \\
3. & Bahasa simbolik \\
& & $\begin{array}{l}\text { Memaknai arti fisik dan } \\
\text { kimia suatu sketsa } \\
\text { gambar. }\end{array}$ \\
4. & Konsistensi \\
logis & Pemodelan &
\end{tabular}

\section{Tahap Penyebaran (Dissemination)}

Tahap ini dilakukan penyebaran dengan melakukan sosialisasi kepada dosen dan mahasiswa terhadap modul yang telah divalidasi oleh para validator (ahli) dan telah diuji coba pada responden. Sosialisasi modul ini dimaksudkan untuk memperkenalkan modul yang telah dikembangkan dan telah memenuhi syarat sehingga dapat digunakan sehingga dapat digunakan pada proses pembelajaran. Akan tetapi, karena adanya keterbatasan waktu maka proses penyebaran atau dissemination ini tidak dilaksanakan, sehingga penelitian ini hanya dilakukan sampai tahap pengembangan (development) yaitu pada tahap uji coba terbatas. 


\section{SIMPULAN}

Berdasarkan data hasil penelitian dan pembahasan, dapat disimpulkan bahwa pengembangan modul praktikum kimia bahan alam berbasis generik sains tentang isolasi kafein dari bubuk kopi yang dikembangkan menggunkan model 4D telah terlaksana dan diperoleh modul praktikum kimia bahan alam berbasis generik sains yang bersifat layak dan sangat praktis digunakan dalam proses pembelajaran.

\section{SARAN}

Diharapkan penelitian selanjutnya dapat dilakukan sampai tahap penyebaran (dissemination) dengan melakukan sosialisasi terhadap modul praktikum yang dikembangkan kepada dosen dan mahasiswa.

Selain itu, pada penelitian ini variabel yang diteliti hanya kelayakan dan kepraktisan, sehingga penelitian selanjutnya diharapkan untuk menggunakan tiga variabel yaitu variabel kelayakan, kepraktisan dan keefektifan.

Untuk analisis lebih lanjut, dapat pula ditambahkan dengan jenis spektroskopi lainnya, seperti H-NMR dan C-NMR. Sehingga diharapkan mahasiswa mendapatkan pengetahuan dan pengalaman yang lebih luas tentang analisis spektroskopi.

\section{DAFTAR PUSTAKA}

Agustin, Rika R., (2013). Pengembangan Keterampilan Generik Sains melalui Penggunaan Multimedia Interaktif. Jurnal Pengajaran MIPA, Vol. 18, No. 2 hal: 253-257.

Atun, Sri., (2014). Metode Isolasi dan Identifikasi Struktur Senyawa Organik Kimia Bahan Alam. Jurnal Konservasi Cagar Budaya Borobudur, Vol. 8, No. 2 hal: 53-61.

Erawanto, U. dan Santoso, E., (2016). Pengembangan Modul Pembelajaran Berbasis Masalah untuk Membantu Meningkatkan Berpikir Kreatif Mahasiswa. Jurnal Inovasi Pembelajaran, Vol. 2, No.2 hal: 427-436.
Fajriana, N. H. dan Fajriati, I., (2018). Analisis Kadar Kafein Kopi Arabika (Coffea arabica L.) pada Variasi Temperatur Sangrai secara Spektrofotometri Ultra Violet. Analytical and Environmental Chemistry, Vol. 3, No. 2 hal: 148-162.

Gustinasari, M. Lufri dan Ardi., (2017). Pengembangan Modul Pembelajaran Berbasis Konsep Disertai Contoh pada Materi Sel untuk Siswa SMA. Bioeducation Journal, Vol. 1, No. 1 hal: 60-73.

Hakim, A., Jufri, A. W., Jamaluddin, J., Andayani, Y., Rahayuan, B. D., \& Supriadi, S. (2019). Promoting Students' Metacognition in Natural Product Chemistry Course through Mini Project Laboratory. Open Access Library Journal, 6(10), 1-8.

Mahmudah, S. Sukib, S. dan Hakim, A., (2018). Pengembangan Modul Praktikum Kimia Bahan Alam: Isolasi Trimiristin dari Pala. Chemistry Education Practice, Vol. 1, No. 1 hal: 20- 25.

Misfadhila, S. Zulharmita dan Siska, D. H., (2016). Pembuatan Kafein Salisilat secara Semisintetis dari Bubuk Kopi Olahan Tradisional Kerinci. Jurnal Farmasi Higea, Vol. 8, No. 2 hal: 175188.

Nulhaqim, S. A. Heryadi, R. R. Pancasilawan, R. dan Fedriyansyah, M., (2015). Peranan Perguruan Tinggi dalam Meningkatkan Kualitas Pendidikan di Indonesia untuk Menghadapi ASEA Comunity 2015. Social Work Jurnal, Vol. 6, No. 2 hal: 154-272.

Nugraheni, F. T. Dewi, M. Septiyana, R., (2017). Perbandingan Rendemen Kristal Kafein pada Biji Kopi (Coffea arabica l.) dan Coklat (Theobroma cacao l.) dengan Menggunakan Metode Refluks. Cendekia Journal of Pharmacy, Vol. 1, No. 1 hal: 41-48.

Pujani, Ni Made., (2014). Pengembangan Perangkat Praktikum Ilmu Pengetahuan Bumi dan Antariksa Berbasis Kemampuan Generik Sains untuk Meningkatkan Keterampilan Laboratorium Calon Guru Fisika. Jurnal Pendidikan Indonesia, Vol. 3, No. 2 hal: 471-484.

Sugiyono., (2015). Metode Penelitian Pendidikan Pendekatan Kuantitatif, Kualitatif dan $R \& D$. Penerbit Alfabeta. Bandung. 


\section{Chemistry Education Practice,3 (1), 2020 - 54}

Safitri, Hakim, Sofia

Thiagarajan, Sivasailam, dkk., (1974). Instructional Development for Training Teacher of Exceptional Children. Penerbit National Center for Improvement Educational System. Washinton DC.

Wasia, N. H. Sudarma, I. M. Savalas, L. R. T. dan Hakim, A., 2017. Isolasi Senyawa Sinamaldehid dari Batang Kayu Manis (Cinnamomum Burmanii) dengan Metode Kromatografi Kolom. Jurnal Pijar MIPA, Vol. 12, No. 2 hal: 91-94. 